\title{
The Impact of Malaysian Islamic Revivalism on Zakat Administration
}

\author{
Suhaili Sarif1 ${ }^{1 *}$, Nor 'Azzah Kamri², Azian Madun³ \\ ${ }^{1}$ Department of Shariah and Management, Academy of Islamic Studies, \\ University of Malaya, Kuala Lumpur. \\ ${ }^{2}$ Department of Shariah and Management, Academy of Islamic Studies, \\ University of Malaya, Kuala Lumpur. \\ ${ }^{3}$ Department of Shariah and Management, Academy of Islamic Studies, \\ University of Malaya, Kuala Lumpur.
}

*Corresponding Author, Email: suhaili@um.edu.my

\begin{abstract}
The development and advancement of zakat institution in Malaysia has been through time influenced by the changing social, political and economic situation of the country. An important phenomenon which shaped the institution is Islamic revivalism. Consequently, zakat has been one of the institutions which government keened to enhance. Another factor merits to be considered is the introduction of economic policies in which the government affirmatively inclined towards Malay Muslims enabling them to compete economically with other wealthier races. Within the spirit of the policies together with the direct influence by the emerging factors resulted from the revivalism phenomenon, the government has introduced corporatization of zakat institution, a modern way of zakat management. This article aims to survey the development of zakat in Malaysia which reflects the continuous process of Islamic revivalism in the nation. As we shall see throughout the discussion, the role of zakat institution has been through time expanded to be one of the national economic tools.
\end{abstract}

Keywords: zakat administration, Islamic revivalism, Malaysia

\section{A. INTRODUCTION}

Islamic revivalism which swept Malaysia since 1970-s is an important subject in the discussion of religious development in Malaysia. The phenomenon is to certain extent associated with the change of Muslims behaviour and the shift of government perception towards Islam. In general, the ambiance of the revival period features among other the proliferation of religious groups who call society and government for more Islamic observance. On top of that, the general outlook of Muslims in Malaysia has also gradually changed with religious practices were more observed than ever before.

As a reaction to the revival challenge, the government has initiated Islamization projects which included the improvement and modernization of zakat institution. As a result of an improved attention given by the government, zakat collection in terms of volume has consistently increased.

From government perspective, zakat is a strategic fund merits to be explored and developed, so that it can be used to improve the economic condition of Muslims. The government in this aspect has used the institution in accordance to national inspiration which clearly outlined in economic policies that Muslim Malays should be helped to be competitive against other races. Thus, zakat in this aspect, has been in such a way moulded towards achieving such objective. This indicates that zakat has been perceived as not merely a religious piety, but an important policy in state 
economy. In attracting payment, zakat authorities has been using propagation approach in which Muslim society is seemed to be more willing to respond. This indirectly shows that the approach introduced earlier by religious groups has been slowly accepted and adopted by the government.

This paper aims to survey the general phenomenon of revivalism and its manifestation towards zakat institution. To achieve its objective, this paper discusses the brief development of zakat in Malaysia which reflects the gradual change of the institution alongside the backdrop of Islamic revivalism and other socio political changes in the nation. As we shall see throughout the discussion, zakat institution, apart from its fundamental role as religious duty for individual Muslims, has been through time transformed to be one of the national economic tools. Pertaining to this particular subject, although a few publications have very briefly noted the advancement of zakat as one example of the government Islamization program, none of them has put the institution into special context. For this reason, the present paper is, among other purposes, trying to fill the gap.

\section{B. METHODOLOGY}

This paper aims to survey the general phenomenon of revivalism and its manifestation towards zakat institution. To achieve its objective, this paper discusses the brief development of zakat in Malaysia which reflects the gradual change of the institution alongside the backdrop of Islamic revivalism and other socio political changes in the nation. As we shall see throughout the discussion, zakat institution, apart from its fundamental role as religious duty for individual Muslims, has been through time transformed to be one of the national economic tools. Pertaining to this particular subject, although a few publications have very briefly noted the advancement of zakat as one example of the government Islamization program, none of them has put the institution into special context. For this reason, the present paper is, among other purposes, trying to fill the gap.

\section{RESULT AND DISCUSSION}

\section{Islamic Revival}

\section{a. Catalysing A Broader Role of Islam}

The phenomenon of Islamic revival has been characterised by, among others, the proliferation of religious organizations and the significant increase in religious awareness among Muslims. There were many Islamic movements in operation at that time, most notably Angkatan Belia Islam Malaysia (ABIM), Jamaat Tabligh and Darul Arqam.

ABIM was established in 1971 by several alumni of the National Association of Malaysian Islamic Students (PKPIM) which mainly provided rooms for graduates and young professionals who were initially active in university student associations (Judith Nagata, 1980). Since its formation, the movement has received strong support mainly from youth in higher institutions where both have strong relations and similar aspirations (Jomo K. Sundaram \& Ahmad Shabery Cheek, 1988). Another movement was Darul Arqam which was established in 1968 by Ashaari Muhammad (Ahmad Fauzi bin Abdul Hamid, 1998). Both groups- ABIM and Darul Arqam- eagerly attempted to solve the nation's problem through Islam. The latter despite having a more or less similar orientation with the former, initially showed no interest in politics and less in challenging the ruling party. Darul Arqam grew by setting up private communities in Sungai Penchala, Terengganu, 
Penang and many others where the followers tended to show a certain standard of attire such as wearing robes and turbans (Mohamad Abu Bakar, 1981).

The Jamaat Tabligh is another well-known group in Malaysia. It was a missionary movement working on a grass roots level of community which originated from Delhi, India and was founded by Muhammad llyas, a Deoband alumnus in 1926 (Peter Mandaville, 2009). The group practically emulates the practice of its Indian forebearer of travelling in specially dispatched missionary groups. Making local mosques their makeshift headquarters, a group of missionaries will visit local Muslims on a door-to door basis and invite them to the daily prayer congregation in the nearest mosque where further sessions of ta'lim (imparting of knowledge) and bayan (lectures on the necessity and nature of the Tabligh's work) will then be delivered (Ahmad Fauzi bin Abdul Hamid 2009).

The emergence of these religious groups has been a challenge to the government in many aspects. For example, ABIM has given political pressure to the government by aligning itself with an opposition Islamic party. Showing their support to the Pan Islamic Party (PAS), a few ABIM members ran for PAS candidature in the 1978 general election. Besides launching campaigns to support PAS, three of ABIM's top leaders campaigned on the PAS's ticket. As a direct result from the collaboration, the societal support for PAS was dramatically growing, especially in urban areas, where the party was initially the least popular (Jomo K. Sundaram \& Ahmad Shabery Cheek, 1988).

Apart from that, the organization was also aiming at the formation of Islamic state. This actually contradicted with the existing role of Islam in the nation. In this particular context, although Islam is stipulated as official religion in Malaysian constitution, the draft commission clearly reported that the position of Islam does not imply that the state is a religious one. The provision was merely intended to fulfil the ceremonial role of solemnization (Joseph M. Fernando 2006). While the government was strongly of the view that Islam should remain as it was, the Islamic groups on the other hand called for further and deeper Islamization towards the ultimate formation of a complete Islamic state (Chandra Muzaffar 2008, Chandra Muzaffar 1989).

However, the views of each organization with regard to political or state matters may vary. ABIM, in this regard, for instance held that declaring Islam as the nation's official religion was inadequate. They demanded a clear avowal of a complete Islamic state where the state law must be based on Sharia. Besides that, the state economy must be freed from any element of interest or usury with a complete implementation of zakat replacing the existing taxation system (Jomo K. Sundaram \& Ahmad Shabery Cheek, 1988). Meanwhile, Al-Arqam, amidst having similar aim with ABIM, have introduced a rather a different way of Islamization. In achieving its objective, the group has set up its own villages all over Malaysia in which its members tried to strictly observe the Islamic principles in their daily life. In this context, they initiated an Islamization process beginning from individual level and small group of people by building a "miniature model" of truly Muslim community with the belief that a successful model can be replicated later by Muslim society at large (Mohamad Abu Bakar, 1981).

Darul Arqam used to criticize all Islamization programs initiated by the government and other religious organizations. According to them, those programs tended to merely rhetoric, slogans and seminars rather than the effort and struggle to establish a truly Islamic state (Jomo K. Sundaram \& Ahmad Shabery Cheek, 1988). It is unfortunate however that the movement was totally banned by the government in 1994 as a result of allegations of deviancy due to the observation of Aurad Muhammadiyya (a systematic chanting of dhikr as practiced by sufis) together with the fanaticism 
of the members towards their leader Ashaari, and amid accusations of threats to national security (Ahmad Fauzi bin Abdul Hamid, 1998). Such an action strongly indicated that the government is not hesitant to do whatever it takes to get rid of any threatening element of political stability of the nation and the interest of its party's survival.

Besides the proliferation of religious groups, the revival phenomenon was also clearly expressed through the gradual change of the landscape of Muslim practices. It was widely observed that more and more Muslims returned to mosques and surau (prayer houses) (Hussin Mutalib 1990). Friday prayers, religious lectures and other events are now a regular part of the youth social scene (Judith Nagata,1980). The Islamic garb (the apparel which covers majority of female body part) has been widely chosen by a majority of Muslim females. Muslims have also become considerably concerned over their dietary rules by only consuming whatever they have been assured to be halal (Ahmad Fauzi bin Abdul Hamid 1998). All of these features gradually became norms and as we could currently see that they are now considered embedded attributes in general Muslims in Malaysia.

Responding to the phenomenon, government has shown more concern over Islam. The government, gradually over time, has introduced its own Islamization projects in order to deter the majority Muslims from being attracted by opposition appeals. Since 1980-s, the government accordingly has introduced Islamization programs such as formation of Islamic banking, establishing International Islamic University and also empowering zakat institution. In this context, the government brilliantly recognized the potential link between development and Islam through which in many instances Islamic institutions have been strengthened and empowered. In the government's view, Islam should bring a better life for Muslims in particular and all Malaysians in general.

One might think why the government came to the point of such projects. In this regard, we should look into historical context of Malaysian economic background prior to 1970s. It is worth mentioning that being ethnically multiracial, a clear dividing line of economic imbalance across ethnic groups has culminated in the 1969 racial riot. The majority ethnic Muslim Malays were economically less fortunate. Looking at the national statistics in early 1970 s for example, the Malays had the lowest average household income of RM 172 per month as compared to the other two dominant races, Chinese and Indian, who respectively secured RM394 and RM304. In addition, the Malays also constituted $65 \%$ of the total poor in the country (Firdaus Abdullah, 1997).

As an immediate response to the riot, the government initiated an economic policy which affirmatively inclined the Malays towards the belief that political stability and national unity could only be attained if the majority received a fair allocation of the nation's wealth (Government of Malaysia, 1971). The New Economic Policy or NEP (1970-1990) which covered four 5-year Malaysian plans was not merely an economic program. It was also a socio-political agenda to ensure equitable distribution among ethnic groups, to promote national unity and maintain political stability (Firdaus Abdullah, 1997). The spirit and overriding objective of the NEP have been continuously maintained by the subsequent two policies, the National Development Policy (19902000) and National Vision Policy (2001-2010). Each of these covered two 5-year plans (Economic Planning Unit, Prime Minister's Department 2004). In this regard the government, in realizing that racial harmony is a key element of the national wellbeing, has done what was required to restore and sustain such a positive situation.

The national historical and socio economic background as mention above, can give us a brief picture regarding the reason why the government introduce such projects. Being the fact that 
Malays are also Muslims, any improvement in Islamic institutions especially which have economic potential will directly help improving their economic welfare. Consistent with this approach, the government has introduced a broader definition of Islamization encompassing all aspects of Muslims life especially in economic perspective. The Prime Minister himself is of the opinion that the Islamic state does not merely implement Sharia; rather, he bases his account of government success on how well it upholds economic development, gender equality, social justice and cultural Islamization (Chandra Muzaffar 2008).

As far as zakat is concerned, the government has initiated the improvement of the zakat institution which to that end, the element of better fund management has been introduced. As the new management of zakat institution approach has been extremely well carried out and adopted, the institution has been gradually driven towards complementing national aims of empowering Malays. The evolving process and the interesting pattern of its institutional development will be predominant in the subsequent sections.

\section{Limited Development of Zakat in Malaysia - Pre Islamic Revivalism}

As Malaysia is a federation, the power to govern matters pertaining to Islam has remained in the hands of the individual states, with the federal government dominant in the handling of many other issues such as security, external and internal affairs, economics and civil law (Refer to the Federal List of Power, Constitution of Malaysia). It is, however, still a duty of federation within the federal territories (Kuala Lumpur, Labuan and Putrajaya) to administer Islamic matters such as providing religious institutions, including zakat, with the necessary bureaucratic support and infrastructure.

As the paper surveys the impact of revivalism towards the development of zakat, it is important for us to briefly understand about the pre revivalism condition of zakat. In this section, although the renewed interests in Islam could be traced as early as 1970s, its significant effects towards zakat could only be seen by the end of 1980s and 1990s. Hence, the details and related statistics shown in this section, although dated until 1980s, are still considered as part of prior revival practice. As such, this paper considers the process of corporatization, a new type of zakat management started in early 1990s, as a marking demarcation between two phases. Such a process will be thoroughly discussed in the next section.

The zakat institution in Malaysia has formally evolved since the early twentieth century in conjunction with the establishment of state religious councils (Mohamed bin Abdul Wahab, 1995). Previously, zakat was a purely personal matter, the proceeds of which were mostly directed towards eligible recipients based on personal preference (Abdul Aziz bin Muhammad, 1993). The process of incorporating the religious practice under state administration began as early as 1916 in Kelantan, followed by the adoption of similar systems in other states such as Perlis in 1930, Johor in 1934, Kedah in 1936, Selangor in 1952, Pahang in 1956, Pulau Pinang and Melaka in 1959 and Federal Territory in 1974 (Ahmad Ibrahim, 1965). The system of collection and disbursement of zakat has been respectively stipulated in individual states' religious laws, which vary slightly from one to another (Ahmad Ibrahim 1965).

The development from the early $20^{\text {th }}$ century until the end of the 1980s was generally unsatisfactory. Revenue collected during this phase was mainly from two sources; zakat al-fitr, the due that the majority of Muslims had long since performed without fail, and also zakat on cereal (particularly unhusked rice) (Aidit bin Ghazali, 1991, Aidit bin Ghazali 1988). Contributions from other types of wealth were relatively inconspicuous. The pattern of collection of zakat al-fitr within the total collected zakat fund can be observed in the combined records from several states (The 
collection and disbursement of the fund at the time were not properly recorded by Religious councils. This resulted the study regarding the institution has failed to unveiled the complete data pertaining to its administration), as follows:

Table 1: Zakat al-Fitr Collection in Proportion to Total Collection in Malaysia (in RM mil) (The data are confined to the collection in West Malaysian States which include Federal Territory, Selangor, Pahang, Perak, Johor, Penang, Negeri Sembilan, Melaka, Perlis, Kelantan, Kedah, Terengganu)

\begin{tabular}{|c|c|c|c|}
\hline Year & Zakat al-Fitr Collection & Total Zakat Collection & Percentage \\
\hline 1984 & 10.09 & 19.81 & 51 \\
\hline 1985 & 10.48 & 24.31 & 43 \\
\hline 1986 & 11.97 & 27.69 & 43 \\
\hline 1987 & 12.58 & 29.34 & 42 \\
\hline 1988 & 12.28 & 23.63 & 52 \\
\hline
\end{tabular}

Source: Mohamed bin Abdul Wahab et.al (1995), "Case Study: Malaysia in Institutional Framework of Zakah: Dimension and Implication" in Institutional Framework of Zakah: Dimensions and Implications. Jeddah: IDB; Aidit Ghazali (1991), "Zakat Administration in Malaysia" in The Islamic Voluntary Sector in Southeast Asia, Mohamed Ariff (ed). Singapore: Institute of Southeast Asian Studies.

In agrarian states such as Kedah and Perlis, the zakat on cereal had been the most sought-out source (Ismail Muhd Salleh and Rogayah Ngah 1980). This was the wealth that caught the immediate attention of the government for monitoring, as rice cultivation (paddy) was a main contributor to the then rural economy. It also represented an obvious continuation of customary practice whereby, prior to the inception of the formal zakat institution, farmers handed over their harvest to the traditional religious leaders, to show the former's appreciation towards the latter.

The following table 2 clearly shows the large contribution of paddy to the zakat fund in the two mentioned states:

Table 2: Zakat on Cereal in the States of Kedah and Perlis in Proportion to Total Collection from 1983 to 1986

\begin{tabular}{|c|c|c|c|c|c|c|c|c|}
\hline State & & 1983 & & 1984 & & 1985 & & 1986 \\
\hline & & RM (mil) \% & & RM (mil) $\%$ & & $\mathrm{RM}(\mathrm{mil}) \quad \%$ & & RM (mil) $\%$ \\
\hline Kedah & 1.29 & 100 & 1.63 & 100 & 1.66 & 100 & 2.03 & 100 \\
\hline Perlis & 0.43 & 62 & 0.74 & 66 & 0.61 & 64 & 0.75 & 67 \\
\hline
\end{tabular}

Source: Mohamed bin Abdul Wahab et.al (1995), "Case Study: Malaysia in Institutional Framework of Zakah: Dimension and Implication" in Institutional Framework of Zakah: Dimensions and Implications. Jeddah: IDB; Aidit Ghazali (1991), "Zakat Administration in Malaysia" in The Islamic Voluntary Sector in Southeast Asia, Mohamed Ariff (ed). Singapore: Institute of Southeast Asian Studies.

It is undeniable that other types of wealth such as property and business also contributed to the zakat collection. It is unfortunate however; these types of zakat were not given much attention by religious councils. In this respect, the payment was merely based on self-assessment and had to be made directly to the district zakat institutions. Unlike zakat al-fitr and zakat on cereal, which were closely monitored by local collectors, most states were unauthorized to collect payment from other than the two main sources (Aidit bin Ghazali 1991).

As for the disbursement side, the pattern of zakat spending in this period was not predominantly directed towards the Muslims' economic improvement. The major portion of the collected fund went on administrative expenses and to other religious developments, such as the building of mosques and funding for Islamic propagation activities under the name of 'amil (zakat collector) and fi sabilillah (in the cause of God) (Abdul Aziz bin Muhammad, 1993). With limited funding from government, the religions councils are forced to turn to zakat for their main financial support, apart from religious financial sources such as waqf (Islamic Trust) and voluntary charity (Abdul Aziz bin Muhammad 1993). 
Table 3: Disbursement Based on Eligible Recipients by Selected State in 1986 (in RM)*

\begin{tabular}{|c|c|c|c|c|c|c|c|c|}
\hline State & Miskin $^{*}$ & Faqir* & Amil $^{*}$ & Muallaf* & $\mid l b n$ al-Sabil $\left.\right|^{*}$ & Fi Sabilillah* $^{*}$ & Gharimin* & Riqab* $^{*}$ \\
\hline Perlis & \multicolumn{2}{|c|}{129,895} & 268,115 & 10,265 & 279 & 440,223 & - & - \\
\hline Kelantan & \multicolumn{2}{|c|}{505,774} & 362,486 & 26,776 & 2,857 & $1,738,197$ & - & - \\
\hline Perak & \multicolumn{2}{|c|}{758,500} & 262,635 & 126,002 & 3,475 & 577,563 & - & - \\
\hline Selangor & 416,245 & 388,113 & 252,000 & 305,500 & 160,363 & 263,594 & 287,280 & 155,819 \\
\hline Federal Territory & 200,080 & 569,660 & 114,360 & 179,480 & 2,850 & 527,220 & 38,400 & - \\
\hline Negeri Sembilan & \multicolumn{2}{|c|}{150,345} & 127,095 & 5,868 & 964 & 435,740 & - & - \\
\hline Melaka & 77,897 & 78,012 & 85,192 & 2,560 & 810 & 20,910 & - & - \\
\hline Johor & 312,198 & 331,345 & 429,271 & 92,796 & 5,248 & - & 1,925 & - \\
\hline Kedah & \multicolumn{2}{|c|}{47,710} & 220,548 & 16,122 & - & 215,965 & 900 & - \\
\hline
\end{tabular}

Source: Mohamed bin Abdul Wahab et.al (1995), "Case Study: Malaysia in Institutional Framework of Zakah: Dimension and Implication" in Institutional Framework of Zakah: Dimensions and Implications. Jeddah: IDB; Aidit Ghazali (1991), "Zakat Administration in Malaysia" in The Islamic Voluntary Sector in Southeast Asia, Mohamed Ariff (ed). Singapore: Institute of Southeast Asian Studies.

*List of eligible recipients (Abdul Aziz bin Muhammad, 1993, Aidit bin Ghazali 1991, Yusuf alQardawi, 1999):

1. Miskin : poor

2. Faqir : needy or poorest

3. 'Amil : zakat collector

4. Mu'allaf : those whose hearts are to be reconciled or converts

5. Ibn Sabil : wayfarer

6. Fi Sabilillah : in the cause of God (includes good deeds and religious propagation activities in the interest of Islam)

7. Gharimin : debtors

8. Riqab : slaves (includes socials problems creating bondage for Muslims such as drug abuse, illiteracy and prostitution)

The allocation for the poor and needy, as shown in table 3, was usually less than the amount received by fi sabillilah and 'amil except in a few states such as Selangor, Federal Territory and Kedah. Given the fact that in the decade of the 1980s there was still an abundance of poor and needy, the allocation was obviously far from sufficient. In this connection, the fund was normally disbursed only once a year, especially when Muslims were about to celebrate 'eid al-fitr (first day of Islamic calendar of Syawal). The poor and needy hence received a sum that was often barely enough to meet their basic needs. In the 1980s, for example, each poor and needy person received respectively only RM60 and RM100 in Kedah, RM120 and RM327 in Selangor, and RM40 and RM60 in Pahang (Mohd Ali Baharom, 1989, Abdul Fatah Khalid, 1988)). Such a disbursement practice was plainly ineffective in eradicating poverty, let alone improving the people's living conditions.

Based on the retrospective overview of zakat provided in this section, it appears that the administration of zakat in Malaysia was merely facilitating the fulfilment of religious duty by Muslims. Most of the time, the fund was used for religious administration and Islamic propagation in the country. With the limited amounts collected, little improvement of Muslims' economic condition was achieved. In sum, it could be inferred that the zakat institution was then merely perceived as a religious duty with the spending merely within the boundary of religious council's scope of authority, far removed from a close association with the national economy. 


\section{The Impact of Islamic Revival on Zakat Institution}

The significant shift in zakat administration was only materialized in early 1990s. The encouraging improvement of the institution since then could be seen as a manifestation of revivalism. It was one of Islamization projects sponsored by the government towards a new effective way of zakat management called corporatization. As reflected from earlier discussion, it was indeed a reaction of the government towards the national religious revival. We however should aware that the new administration and infrastructure alone are not sufficient without full cooperation from Muslim society. Hence, in this context it can also be considered that the willingness of Muslims to surrender their payment is showing that the spirit and process of revivalism is continuously in place. This evolving situation could be detailed as follows.

\section{a. Modernization through Corporatization - A Good Start from Government and Great Reaction from Society}

The first concrete effort towards better management of zakat was begun in 1991. The new technique of fund management was introduced under the federal government through religious affairs operation in the Federal Territory. The close interrelation between federal government and religious administration in Federal Territory led to the improvement of religious administration in this area easier to implement here than in the other states.

The concept of zakat corporatization was the brainchild of Abdul Rahim Abu Bakar, a former Chief Minister of the state of Pahang, with strong support from Mohd Yusof Noor, the then Minister overseeing religious affairs in the Prime Minister's Department. The process started with a discussion between both individuals on 11 May 1989, during which the former voiced his opinion to the latter on how to improve the zakat collection system (Abd Rahim Bin Abu Bakar, 1991). Through a feasibility study of the proposed new mechanism, it was estimated that in Federal Territory alone, the collected zakat fund should reach around RM60 million ringgit as compared to the then actual collection, which was merely around RM7 million. The meagre collection strongly suggested that the institution was extremely undermanaged at the time (Abd Rahim Bin Abu Bakar, 2007).

Corporatization is a new model of zakat collection, achieved through the establishment of a company or corporate organization, which manages the fund, replacing the traditional personal zakat collector and direct administration by state religious councils. A corporate zakat collector, being a company or organization, is responsible for the complete range of activities such as planning, organizational setup, hiring and training of staff and publishing annual and monthly reports, as well as being accountable for all costs and activities involved in zakat collection (Pusat Pungutan Zakat MAIWP 2003). To ensure that the organization can run viably, it must collect a sufficiently large amount of zakat on behalf of its parent organization (the State Religious Council), and in return it receives the collector's portion at a maximum of one eighth of the total collected sum (Kikue Hamayotsu 2004).

The performance of the new organization under the name of Zakat Collection Center of Federal Territory (Pusat Pungutan Zakat, hereafter referred as PPZ) has indeed been encouraging. Since its inception, the meteoric increase in the collection has exceeded expectations, more than doubling in the first year and rising consistently since then. The collection records from its inception through 2008 are as indicated in the table below. 
Table 4: Zakat Collection in Federal Territory from 1991 to 2008

\begin{tabular}{|c|c|c|c|}
\hline Year & Zakat al-Mal & Zakat al-Fitr & Amount \\
& & & (in RM mil) \\
\hline 1991 & 13.5 & 1.73 & 15.23 \\
\hline 1992 & 20 & 2.14 & 22.14 \\
\hline 1993 & 25.6 & 1.3 & 26.9 \\
\hline 1994 & 33.1 & 1.32 & 34.42 \\
\hline 1995 & 32.3 & 1.38 & 33.68 \\
\hline 1996 & 41.3 & 1.62 & 42.92 \\
\hline 1997 & 50.6 & 2.25 & 52.85 \\
\hline 1998 & 43.6 & 2.17 & 45.77 \\
\hline 1999 & 33.6 & 2.41 & 36.01 \\
\hline 2000 & 56.1 & 2.82 & 58.92 \\
\hline 2001 & 70.3 & 2.59 & 72.89 \\
\hline 2002 & 80.8 & 3.73 & 84.53 \\
\hline 2003 & 92.9 & 3.48 & 96.38 \\
\hline 2004 & 106.7 & 3.93 & 110.63 \\
\hline 2005 & 126.7 & 3.39 & 130.14 \\
\hline 2006 & 143.3 & 5.55 & 148.8 \\
\hline 2007 & 169.2 & 5.4 & 174.6 \\
\hline 2008 & 206.3 & 4.1 & 210.9 \\
\hline
\end{tabular}

Source: Pusat Pungutan Zakat MAIWP, Laporan Tahunan, various issues. Kuala Lumpur: PPZ.

The corporatization of zakat in Federal Territory has inspired other states to follow suit. Consequently Penang, Selangor and Pahang ended by adopting a similar model a few years later (Harian Metro 1992, Ab Rahim Zakaria 2007). More recent developments have shown that only a few states (Kelantan, Terengganu, Perlis, Kedah and Johor) still retain the collection directly under religious councils. However, they too have benefited from the development by introducing some changes, especially use of the comprehensive computerized system; with some new collection practices being gradually adopted (Baitulmal Negeri Perlis, 2009). The pattern of increase in the fund collection signified the effectiveness of the new organization and its acceptance by the Muslim populace. Table 5 below portrays the achievement of the zakat institution from 2000 whereby the collection has reached more than RM one billion in 2008, a tremendous jump from the barely-achieved RM 30 million annually at the end of the 1980s.

Table 5: Zakat Collection by State from 2000 through 2008 (in RM mil)

\begin{tabular}{|c|c|c|c|c|c|c|c|c|c|}
\hline State & $\mathbf{2 0 0 0}$ & $\mathbf{2 0 0 1}$ & $\mathbf{2 0 0 2}$ & $\mathbf{2 0 0 3}$ & $\mathbf{2 0 0 4}$ & $\mathbf{2 0 0 5}$ & $\mathbf{2 0 0 6}$ & $\mathbf{2 0 0 7}$ & $\mathbf{2 0 0 8}$ \\
\hline Federal Territory & 58.92 & 72.89 & 84.5 & 96.38 & 110.63 & 130.14 & 147.59 & 173.82 & 211.36 \\
\hline Selangor & 46.26 & 61.43 & 78.72 & 86.20 & 108.83 & 133.12 & 159.83 & 202.19 & 244.41 \\
\hline Penang & 14.83 & 17.55 & 20.1 & 21.32 & 23.29 & 28 & 30.59 & 37.08 & 41.77 \\
\hline Pahang & 14.43 & 16.62 & 18.38 & 20.61 & 22.92 & 31.03 & 35.97 & 41.49 & 57.94 \\
\hline Negeri Sembilan & 10.62 & 13.23 & 15.02 & 16.52 & 19.04 & 23.09 & 25.82 & 29.36 & 37.41 \\
\hline Melaka & 8.44 & 12.03 & 12.34 & 13.04 & 14.24 & 17.69 & 19.46 & 22.07 & 26.91 \\
\hline Sabah & 6.99 & 5.33 & 6.18 & 5.1 & 7.78 & 11.31 & 16.65 & 17.51 & 23.8 \\
\hline Kelantan & 15.67 & 16.58 & 16.88 & 18.14 & 22.44 & 29.37 & 35.64 & 40.2 & 58.17 \\
\hline Terengganu & 20.76 & 28.25 & 32.98 & 40.06 & 36.15 & 40.37 & 42.87 & 51.44 & 66.2 \\
\hline Perlis & 3.32 & 3.72 & 6.16 & 6.57 & 6.41 & 6.56 & 11.87 & 16.69 & 23.13 \\
\hline Kedah & 11.86 & 12.49 & 18.27 & 18.56 & 22.21 & 30.19 & 35.23 & 36.69 & 53.2 \\
\hline Perak & 16.36 & 20.47 & 20.8 & 21.7 & 25.72 & 27.54 & 33.85 & 41.28 & 57.12 \\
\hline Johor & 28.03 & 31.45 & 29.73 & 33.96 & 38.05 & 49.36 & 54.73 & 73.32 & 100.74 \\
\hline Sarawak & 4.95 & 8.32 & 13.81 & 10.26 & 15.57 & 15.3 & 20.55 & 23.13 & 36.1 \\
\hline Total & 261.44 & 320.37 & 373.92 & 408.43 & 473.26 & 573.08 & 670.64 & 806.28 & 1038.26 \\
\hline
\end{tabular}

Source: Syawal Kasam (2008), "Governing Zakat as a Social Institution: The Malaysian Perspective", in Southeast Asia Zakat Movement, M. Arifin Purwakananta et.al (eds). Jakarta: Forum Zakat, p. 114; Pusat Pungutan Zakat MAIWP, Laporan Zakat, various issues. Kuala Lumpur: PPZ. 
Besides the greater achievement in the amount collected, the type of wealth contributing to the total sum of the fund also changed its pattern. In contrast to the period prior to corporatization, the main source of the zakat is now no longer zakat al-fitr and cereals; rather the current greatest contributors are personal income as well as business earnings. For example in 2008, from the over a billion total national zakat collection, zakat al-fitr contributed only RM 83.87 million, indicating that the new type of zakat management has successfully encouraged Muslims to pay more zakat al-mal. As far as the type of wealth constituting zakat al-mal is concerned, table 6 clearly shows that the 2008's zakat from personal vocations and business are the two largest sources of wealth for the collection.

Table 6: Contribution from Personal Income and Business Income to Total Zakat Collection in 2008 (in RM mil)

\begin{tabular}{|l|c|c|c|c|}
\hline State & $\begin{array}{c}\text { Personal } \\
\text { Income (A) }\end{array}$ & $\begin{array}{c}\text { Business } \\
\text { Income (B) }\end{array}$ & $\begin{array}{c}\text { A+B } \\
\text { Zakat al-Mal }\end{array}$ \\
\hline Federal Territory & 137.57 & 28.7 & 166.27 & 206.26 \\
\hline Selangor & 130.7 & 46.11 & 176.81 & 232.13 \\
\hline Penang & 22.16 & 3.95 & 26.11 & 37.82 \\
\hline Pahang & 17.98 & 24.29 & 42.27 & 50.64 \\
\hline Negeri Sembilan & 14.27 & 9.05 & 23.32 & 33.8 \\
\hline Melaka & 10.3 & 7.17 & 17.47 & 23.97 \\
\hline Sabah & 4.84 & 10.25 & 15.09 & 16.42 \\
\hline Kelantan & 21.09 & 18.6 & 39.69 & 50.15 \\
\hline Terengganu & 23.27 & 20.47 & 43.74 & 60.75 \\
\hline Perlis & 12.28 & 4.37 & 16.65 & 22.3 \\
\hline Kedah & 26.0 & 16.17 & 42.17 & 49.45 \\
\hline Perak & 24.41 & 23.77 & 48.18 & 49.41 \\
\hline Johor & 27.76 & 33.37 & 61.13 & 89.18 \\
\hline Sarawak & 15.91 & 11.94 & 27.85 & 31.93 \\
\hline Total & 488.54 & 258.21 & 746.75 & 954.22 \\
\hline
\end{tabular}

Source: Pusat Pungutan Zakat MAIWP, Laporan Zakat 2008. Kuala Lumpur: PPZ.

The interesting phenomenon revealed by the above table is that personal earnings provided the most wealth collected in the majority of states. Some states, however, recorded that business earnings surpassed the collection from personal income. Although the trend of payment needs to be investigated further, simple observation could indicate that the change in sources of wealth as compared to previous decades reflects the shift in economic activities of Muslims in Malaysia and the economic progress of the country.

The growth in collection however, has posed a challenge to the zakat institution to distribute the fund more effectively. As far as the disbursement aspect is concerned, the greater portion has gone to poverty eradication. The general trend of fund disbursement after the corporatization can be observed in the following tables showing the disbursement statistics for 2000 and 2008.

Table 7: Zakat Disbursement by State in 2000 (in RM mil)

\begin{tabular}{|l|c|c|c|c|c|c|c|c|}
\hline State & Miskin & Faqir & 'Amil & Mu'allaf & Ibn al-Sabil & Fi Sabilillah & Gharimin & Riqab \\
\hline Federal Territory & 11.75 & 3.75 & 8.16 & 0.91 & 0.11 & 20.5 & 0.32 & - \\
\hline Selangor & 4.34 & 1.99 & 4.37 & 2.15 & 0.12 & 12.8 & 1.46 & - \\
\hline Penang & 2.21 & 0.75 & 2.35 & 0.27 & 0.05 & 5.31 & 1.01 & - \\
\hline Negeri Sembilan & \multicolumn{2}{|c|}{1.66} & 1.24 & 0.66 & 0.06 & 1.59 & 3.86 & - \\
\hline Melaka & 1.42 & 2.11 & 1.16 & 0.42 & 0.06 & 1.83 & - & - \\
\hline Sabah & 1.07 & 0.08 & 0.34 & 0.02 & - & - & - & - \\
\hline Kelantan & \multicolumn{2}{|c|}{2.8} & 1.05 & 0.3 & 0.09 & 5.54 & 0.01 & \\
\hline Terengganu & 7.05 & 2.6 & 0.87 & 0.49 & 0.06 & 1.97 & 0.23 & 0.02 \\
\hline Perlis & 1.01 & 0.31 & 0.93 & 0.16 & 0.01 & 2.93 & - & - \\
\hline Kedah & \multicolumn{2}{|c|}{4.62} & 0.77 & 0.26 & 0.07 & 2.06 & 0.02 & - \\
\hline Perak & \multicolumn{2}{|c|}{6.47} & 1.62 & 1.24 & 0.28 & 6.44 & 0.21 & - \\
\hline Johor & 4.65 & 4.83 & 2.01 & 0.03 & 10.8 & 0.12 & - \\
\hline
\end{tabular}


Source: Pusat Pungutan Zakat MAIWP, Laporan Zakat 2000-2001. Kuala Lumpur: PPZ.

Table 8: Zakat Disbursement by State in 2008 (in RM mil)

\begin{tabular}{|l|c|c|c|c|c|c|c|c|}
\hline State & Miskin & Faqir & 'Amil & Mu'allaf & Ibn al-Sabil & Fi Sabilillah & Gharimin & Riqab \\
\hline Federal Territory & 20.51 & 22.67 & 31.64 & 5.65 & 0.4 & 85.04 & 1.65 & - \\
\hline Selangor & 51.17 & 11.39 & 30.39 & 11.67 & 0.69 & 63.6 & 18.98 & 1.08 \\
\hline Penang & 2.19 & 20.3 & 5.45 & 0.76 & 0.14 & 15.72 & 1.02 & - \\
\hline Negeri Sembilan & \multicolumn{2}{|c|}{12.24} & 4.68 & 2.67 & 0.27 & 6.05 & 1.37 & 9.53 \\
\hline Melaka & 6.21 & 1.17 & 4.25 & 1.42 & 0.006 & 7.64 & 0.012 & - \\
\hline Sabah & 4.56 & 6.58 & 2.47 & 1.53 & 0.020 & 4.17 & 0.0004 & - \\
\hline Kelantan & 10.11 & 9.56 & 1.78 & 0.79 & 0.003 & 3.04 & 0.012 & - \\
\hline Terengganu & 13.54 & 3.24 & 9.42 & 1.05 & 0.013 & 8.2 & 0.06 & 0.15 \\
\hline Perlis & 4.08 & 0.84 & 1.38 & 0.18 & 0.004 & 9.35 & 0.005 & - \\
\hline Kedah & 17.62 & 1.85 & 5.841 & 1.01 & 0.22 & 15.59 & 0.002 & - \\
\hline Perak & \multicolumn{2}{|c|}{19.19} & 6.4 & 1.82 & 0.46 & 9.07 & 0.13 & - \\
\hline Johor & 16.8 & 6.68 & 11.37 & 5.43 & 0.13 & 32.07 & 1.79 & - \\
\hline
\end{tabular}

Source: Pusat Pungutan Zakat MAIWP, Laporan Zakat 2008. Kuala Lumpur: PPZ.

The tables 7 and 8 show that in the majority of states, the fund went mostly to four groups of recipients, namely faqir, miskin, 'amil and fi sabilillah. The former two grants reflect the allocation for poverty eradication, while the latter two imply the religious institutions' expenses in every state including zakat itself. As the spending for all these groups has been increasing consistently along with the rising collection, it could be inferred that poverty eradication and financing Islamic institutions are the two aspects of greatest concern in the recent zakat disbursal approaches.

Since Islamic institutions are the responsibility of the state religious councils to finance, it is unsurprising to find that most of the time, the allocation for fi sabilillah and 'amil are among the highest in the majority of states. In the year 2000 , as table 7 clearly shows, the provision for these groups is significantly higher than that for the miskin and faqir combined in the majority of states except three, namely Sabah, Terengganu and Kedah. This pattern, however, changed in 2008 when five of the 12 states in the table 8 distributed more of the fund towards poverty eradication. Such a pattern indicates the increasing concern of the zakat institution and religious authorities about the poverty problem in their respective states.

In addition to the higher disbursement of zakat, various programs have been also introduced under the heading of faqir and miskin for providing the recipients with financial and also nonfinancial support. In Selangor and Federal Territory, zakat authorities for example have outlined more than 20 programs for each faqir and miskin group, ranging from monthly allowances to business aid. Overall, the distribution approach has been shaped in such a way as to raise the living conditions of the recipients (Jabatan Wakaf Zakat dan Haji 2007).

Apart from the initiatives stated above, another improvement in the disbursal approach is that the fund is now distributed for permanent relief of the poor. To achieve this aim, zakat is now disbursed for the purpose of income generation, not merely giving the poor a financial allowance but also providing them with necessary skills so that they can become permanently independent. In this context, Selangor, Federal Territory and Kedah are among states actively offering such a program. Federal Territory and Selangor in 2008 alone spent more than RM three million and RM five million respectively.

Besides the active role of the government in improving its management, it is worth mentioning that the encouraging development was also, to certain extent, induced by the constant growth in Islamic consciousness among Muslims. The PPZ in this respect, based on its own observations, openly admitted the contribution of such factor. This also reflected the direct and indirect impact of 
religious movements, as earlier listed. Although the statement was never systematically proven and merits further investigation, it cannot be totally rejected, in as much as the number of religious movements has continued to increase. ABIM, for example, has 65000 members currently, and actively cooperates with zakat management in various states, especially with the PPZ and Zakat Board of Selangor.

Another interesting element worth to mention is pertaining to the way the corporatized zakat organization operates whereby they prefer to use the approach of persuasion more rather than merely through coercive legal enforcement. As the propagation of Islamic teachings is one of important elements used by religious groups back in 1970s, such a practice clearly indicates that the similar approach is seemed effective to be put into practice in modern zakat administration.

In this particular aspect, it was clearly stated in its objective that the PPZ was also determined to improve the awareness of the population pertaining to their obligation of zakat (Pusat Pungutan Zakat 1994). The commitment was accordingly delivered through the organization's policy of spreading the words pertaining to zakat all over Malaysia. In the early years of its inception for example, the PPZ's officers have delivered up to 600 talks annually all over Malaysia (PPZ has organized 607 zakat talks in 1991, 417 in 1992, 140 in 1993, 116 in 1994 and 154 in 1995. Please refer to zakat reports in the respective year). There were also many discussions and briefings provided by the PPZ regarding the new system for any interested parties. The organization was open to share their expertise with any interested parties - particularly with other states' religious councils. This shows the genuine motive of the PPZ by the fact that it could not manipulate or attract other people who resided outside federal territory to submit their payment to them.

\section{b. Converging Zakat into Malaysian Economic Policy}

The excellent record of collection has induced a positive response and further change in fund management practice in at least two other related aspects: greater federal government interest in zakat administration through improvement of coordination between states, and ultimately, the incorporation of the institution within broader national development policies by means of national plans. The government though time has tried to assert further their power in the institution by trying to initiate a nationally coordinated zakat (This initiative although has been voiced in the 1980-s, the concrete move was only evident on 1992, two years after the corporatization). In 1992 for example, Minister of Finance, together with ministers in the Prime Minister Department, have frequently voiced the government's aspiration of coordinating zakat management in Malaysia (Azhar Mohd Nasir, 1999, Kikue Hamayatsu 2004). On top of that, during the tabling of the 1993 Federal Budget, Finance Minister officially announced that zakat would be collected nationally by Internal Revenue Department (IRD), a federal department collecting taxation (Azhar Mohd Nasir (1999), Berita Harian (1992), "Kutipan Zakat Perlu Rancak", 1992). Through a number of very productive seminars, IRD has also shown its readiness to collect zakat along with other secular taxation (Berita Minggu (1993), Berita Harian (1993), "Boleh Bayar Zakat di JHDN", 1993). These efforts, however, remained as political statements without getting positively accepted by the Rulers Council (Majlis Raja-raja), the highest body, who it was hoped would give a final nod of relinquishing the individual ruler's power over zakat to federal government. Regularly, however, the constitution was made a scapegoat for their reluctance to subscribe to the suggestion (Azhar Mohd Nasir (1999), The Sun (1996), "Special Agency to Collect Zakat From Firms", 1996). The silent rejection of the rulers suggested that they will not easily hand over their power to the federal government, and in the matter of the advancement of religious institution, the cooperation between federal and state is more welcomed rather than solely taken over by the federal. 
From a broader economic development perspective, zakat has also been increasingly seen as a potential tool in poverty eradication, complementing other, secular approaches implemented by the government. The federal government, with regard to this aspect, since early 2000 has been gradually incorporating the fund into national economic plans, something that has never happened before. In 2001, for instance, zakat was included in the Malaysian Prospective Plan (2000-2010), a strategic plan indicating the economic direction of the decade, so that it could be used for the development of Malay Muslims (Government of Malaysia, 2001). This aspiration was again spelt out in the Ninth Malaysia Plan (2006-2010), a more specific economic program expanding the earlier one. The later plan stated that the fund should be directed towards poverty eradication, in the way that the zakat institution in many states is currently inclining. As for effective management, it was recommended that the Zakat Collection Center of Federal Territory should be replicated and corporate management adopted. Additionally, the plan stipulated that the Department of Waqf, Zakat and Hajj, a new established federal department, would be responsible for monitoring the development and would stimulate cooperation between states (Government of Malaysia, 2006, Abdullah Ahmad Badawi, 2006, Dewan Rakyat, 2006). This obviously shows recognition of the huge potential of the fund in the economy and provides a starting point for a more serious convergence between zakat and other economic institutions. The plan makes it explicit that zakat is increasingly a focus of governmental attention, which is undeniably good for its further advancement. It also conveys an implicit view that the government needs to venture on a lucrative source of funding to help achieve its long-term objective, namely, empowering Malays economically against non-Malays.

From the discussion, it could be concluded that the introduction of corporatization has been a revolutionizing factor leading to the increased collection and advancement of the zakat institution since the 1990s, and ultimately to greater fund distribution. Since the fund has the potential for poverty eradication, it can also be suggested that the institution should play a greater part in economic development beyond its original role as an expression of religious piety.

\section{CONCLUSION}

As has been self-evident throughout the discussion, the Islamic revivalism in Malaysia has considerably changed the overall practice of zakat. The religious groups which ploriferated during that period have called society and government for greater commitment towards Islam. In addition, there was also a significant change in the outlooks of Muslims in general where they tend to show greater observance towards the Islamic duty and rituals. The phenomenon consequently has given a tremendous political and social pressure to the government in which it must accordingly respond. As a response, the government has then become more concern over Islamic institutions. In this aspect, the government has to reconcile between the demand of increasing Islamic awareness and the existed national economic agenda by creatively opting for Islamization through which Islam and Muslim is empowered economically.

As far as the zakat institution is concerned, the government has initiated corporatization, a modern way of managing the fund. In this aspect, there are elements of revivalism could be observed in the newer practice of zakat administration signifying the influence of the phenomenon in the institution. For example, the new zakat administrations prefer to use propagation approach to persuade payment and do not focus on legal enforcement. On the other hand, Muslims also have shown a better reaction by gradually increasing their payment to the level that never been happened before. Ultimately, the government through time has slowly embraced the zakat institution into the broader national economic plan. All of these features denote a continuous manifestation of evolving process of revivalism in the nation. 
In sum, the revivalism has changed the perception of society and government towards zakat. From a broader context, the institution is no longer perceived as merely a religious duty but also as part of national tool of economic development. The government in particular and Muslims in general are gradually aware of the importance of the fund in helping them to achieve national development goal, far beyond its earlier role as a fund to only show appreciation towards religious people or to help running religious institutions. Should we look into the current development we will find that any improvement in the institution is definitely heading towards the similar direction. 


\section{References}

Ab. Rahim Zakaria (2007), "Pengurusan Zakat Kontemporari", Jurnal Pengurusan JWZH, 1(1).

Abd Rahim bin Abu Bakar (1991), Speech text in official launching of corporate zakat collection in PPZ, 8 March 1991.

Abd Rahim bin Abu Bakar (2007), "Teks Syarahan Seminar Budaya Pengurusan Zakat di Malaysia: Profesionalisme Berbanding Tradisionalisme" in Laporan Zakat 2006. Kuala Lumpur: PPZ.

Abdul Aziz bin Muhammad (1993), Zakat and Rural Development in Malaysia. Kuala Lumpur: Berita Publishing.

Abdul Fatah Khalid (1988), "Islamic Law and Land in the State of Selangor, Malaysia: Problem of Administration and Islamization", (Phd Thesis, University of Edinburgh).

Abdullah Ahmad Badawi (2006), Prime Minister Speech at the tabling of the motion on the Ninth Malaysia Plan 2006-2010, Dewan Rakyat, 31 March 2006.

Ahmad Fauzi bin Abdul Hamid (1998), "Islamic Resurgence in the Periphery: A Study of Political Islam in Contemporary Malaysia with Special Reference to the Darul Arqam Movement", (Phd Thesis, University of Newcastle Upon Tyne).

(2009), "Transnational Islam in Malaysia" in Transnational Islam in South and Southeast Asia; Movements, Networks and Conflicts Dynamics, USA: The National Bureau of Asian Research.

Ahmad Ibrahim (1965), Islamic Law in Malaya. Singapore: Malaysian Sociological Research Institute Ltd.

Aidit Ghazali (1988), Zakat, Satu Tinjauan. Petaling Jaya: IBS Buku.

(1991), "Zakat Administration in Malaysia" in The Islamic Voluntary Sector in Southeast Asia, Mohamed Ariff (ed). Singapore: Institute of Southeast Asian Studies.

Azhar Mohd Nasir (1999), "Development of the Secular and Religious Taxation System in Peninsular Malaysia", (Phd Thesis, University of Edinburgh).

Baitulmal Negeri Perlis (2009), "Peranan Baitulmal Perlis" in Buletin Baitulmal, 2 ${ }^{\text {nd }}$ edition, 2009.

Berita Harian (1992), "Kutipan Zakat Perlu Rancak", 19 November 1992.

(1993), "Boleh Bayar Zakat di JHDN", 1 March 1993.

Berita Minggu (1993), "Bayaran Zakat, Cukai Pendapatan Diselaras”, 28 February 1993.

Chandra Muzaffar (1989), Challenges and Choices in Malaysia Politics and Society. Penang: Aliran Kesedaran Negara. 
Chandra Muzaffar (2008), "The Islamic State Issue in Malaysia: Perceptions and Realities", (Conference on Progressive Islam and the State in Contemporary Muslim Society, The Institute of Defence and Strategic Studies, 7-8 March, Singapore).

Economic Planning Unit, http://www.epu.gov.my/chapter1, accessed on 18 August 2010.

Economic Planning Unit, Prime Minister's Department (2004), "Malaysia: 30 Years of Poverty Reduction, Growth and Racial Harmony", (Paper presented in Scaling Up Poverty Reduction: A Global Learning Process and Conference, 25-27 May, Shanghai).

Federal List of Power, Constitution of Malaysia "The Constitution of Malaysia", (Federal list), http://confinder.richmond.edu/admin/docs/malaysia.pdf, accessed on 18 February 2010.

Firdaus Abdullah (1997), "Affirmative Action Policy in Malaysia: To Restructure Society, to Eradicate Poverty", Ethnic Studies Report, XV(2).

Government of Malaysia (1971), Second Malaysia Plan 1971-1975. Kuala Lumpur: Government Printers.

(2001), Third Outline Perspective Plan. Putrajaya: Government Printers, p. 98.

(2006), Ninth Malaysia Plan 2006-2010. Putrajaya: The Economic Planning Unit, Prime Minister's Department.

Harian Metro (1992), "Pungutan Zakat WP Menjadi Contoh”, 21 January 1992.

http://e-maik.my/index.php?option= com_content\&view=article\&id=263\&ltemid=604, accessed on 27 August 2010

Hussin Mutalib (1990), "Islamic Revivalism in Asian States: Political Implications", Asian Survey, $9(30)$.

(1993), Islam in Malaysia, From Revivalism to Islamic State. Singapore: Singapore University Press.

Ishak Shari (2000), "Economic Growth and Income Inequality in Malaysia", Journal of Asia Pacific Economy, 5(1/2).

Ismail Muhd Salleh and Rogayah Ngah (1980), "Distribution of Zakat Burden on Padi Producers in Malaysia", in Some Aspects of the Economics of Zakah, M. Raqibuz Zaman (ed). Plainfield: The Association of Muslim Scientists.

Jabatan Wakaf, Zakat dan Haji (2007), Manual Pengurusan Agihan Zakat. Putrajaya: JAWHAR.

Jabatan Zakat Kedah (1991), Laporan Aktiviti-Aktiviti Zakat Negeri Kedah Bagi Tahun 1986-1990. Alor Star: Jabatan Zakat Kedah.

Jomo K. S. (2004), "The New Economic Policy and Interethnic Relations in Malaysia", (Programme Paper 7, September 2004, United Nations Research Institute for Social Development, Geneva). 
Jomo K. Sundaram \& Ahmad Shabery Cheek (1988), "The Politics of Malaysia's Islamic Resurgence", Third World Quarterly, 2(10).

Joseph M. Fernando (2006), "The Position of Islam in the Constitution of Malaysia", Journal of South East Asian Studies, 2 (37).

Judith Nagata (1980), "Religious Ideology and Social Change: The Islamic Revival in Malaysia", Pacific Affairs, 53(3).

(1982), "Islamic Revival and the Problem of Legitimacy Among Rural Religious Elites in Malaysia", Man, 1 (17).

Kelantan Council of Religion and Malay Custom and Kathis Courts Enactment 1953.

Kikue Hamayotsu (2002), "Islam and Nation Building in Southeast Asia: Malaysia and Indonesia in Comparative Perspective", Pacific Affairs, 3 (75).

(2004), "Islamisation, Patronage and Political Ascendancy: The Politics and Business of Islam in Malaysia" in The State of Malaysia - Ethnicity, Equity and Reform, Edmund Terence Gomez (ed). RoutledgeCurzon Malaysian Studies Series.

Majlis Agama Islam Kelantan,

Majlis Agama Islam Negeri Johor, http://www.maij.gov.my/utama.htm, accessed on 27 August 2010.

Mohamad Abu Bakar (1981), "Islamic Revivalism and Political Process in Malaysia", Asian Survey, $21(10)$.

Mohamed bin Abdul Wahab et.al (1995), "Case Study: Malaysia in Institutional Framework of Zakah: Dimension and Implication" in Institutional Framework of Zakah: Dimensions and Implications. Jeddah: IDB.

Mohd Ali Baharom (1989), Zakat Ditinjau Dari Perspektif Sosial, Undang-undang dan Taksiran. Kuala Lumpur: ABIM.

Moshe Yegar (1979), Islam and Islamic Institutions in British Malaya: Policies and Implementation. The Hebrew University, Jerusalem: Magnes Press.

Pahang Administration of the Law of Religion of Islam Enactment 1956.

Peter Mandaville (2009), "Transnational Islam in Asia: Background, Typology and Conceptual Overview", in Transnational Islam in South and Southeast Asia; Movements, Networks and Conflicts Dynamics, USA: The National Bureau of Asian Research.

Pusat Pungutan Zakat (1994), Laporan Zakat 1993. Kuala Lumpur: PPZ.

Pusat Pungutan Zakat MAIWP (2003), Laporan 2000-2001. Kuala Lumpur: PPZ.

Selangor Administration of Muslim Law Enactment 1952. 
Syawal Kasam (2008), "Governing Zakat as a Social Institution: The Malaysian Perspective", in Southeast Asia Zakat Movement, M. Arifin Purwakananta et.al (eds). Jakarta: Forum Zakat.

The Sun (1996), "Special Agency to Collect Zakat From Firms", 16 October 1996.

Unit Pemodenan Tadbiran dan Perancangan Tenaga Manusia, Jabatan Perdana Menteri (1984), Laporan Kajian Penyusunan Semula Majlis/Pejabat Agama Islam Negeri-negeri, Kuala Lumpur: MAMPU.

Yusuf al-Qardawi (1999), Fiqh az-Zakat: A Comparative Study. London: Dar al-Taqwa Ltd.

Zainah Anwar (1987), Islamic Revivalism in Malaysia: Dakwah Among Students. Petaling Jaya: Pelanduk Publication. 